\title{
ANALISA KUALITAS AIR MINUM ISI ULANG DAN KEMASAN DI KELURAHAN KENTEN LAUT KABUPATEN BANYUASIN
}

\author{
Muhrinsyah Fatimura $^{1}$, Rully Masriatini ${ }^{* 1}$, Andika Pratama ${ }^{1}$ \\ ${ }^{1)}$ Program Studi Teknik Kimia, Fakultas Teknik, Universitas PGRI Palembang \\ *)email: rullyfir@gmail.com
}

\begin{abstract}
Abstrak
Air merupakan salah satu kebutuhan wajib untuk keberlangsungan hidup . Untuk memenuhi kebutuhan tersebut di era sekarang ini banyak tersedia dengan mudah air minum isi ulang dan dalam kemasan .Dalam proses pengisian dan pengolahan air tentunya banyak faktor yang akan mempengaruhi kualitas dari air isi ulang dan kemasan tersebut apakah layak atau sesuai kualitas yang harus sesuai standar di dalam Peraturan Menteri Kesehatan RI No. 492/MENKES/PER/IV/2010. Pada penelitian ini akan menguji kualitas beberapa air pada depot air minum isi ulang dan kemasan yang beredar di daerah Kenten laut Kabupaten Banyuasin . Parameter yang akan di analisa yaitu pH, TDS, bau, rasa, warna, temperatur dan kandungan bakteri. Penelitian ini dilakukan dengan metode sampling dan analisis di laboratorium. Dari hasil analisa untuk parameter fisika untuk TDS semua sampel 1 sampai 9 masih dalam limit kontrol di bawah 500 ppm ,untuk rasa semua sampel memiliki rasa yaitu rasa pahit, asam, kelat, lengket, beraroma kelapa kecuali pada sampel, Untuk warna dari sampel 1 sampai 9 tidak berwarna ,sedangakn bau semua sampel tidak berbau. untuk parameter kimia, pada sampel 1 sampai 6 memiliki $\mathrm{pH}$ yang cenderung asam yaitu kisaran 4,4- 5,8, sedangkan untuk analisa kandungan bakteri E Coli dari 9 sampel yang di uji tidak terdapat kontaminasi bakteri E.coli. Dari hasil analisa menunjukan bahwa masih ada beberapa parameter yang masih belum memenuhi persyaratan Permenkes RI No. 492/Menkes/Per/IV/2010.
\end{abstract}

Kata kunci: air, parameter fisika,kimia ,biologi

\section{PENDAHULUAN}

Pentingnya air bagi kelangsungan hidup manusia karena sebagai makhluk hidup manuisa sangat membutuhkan air dalam hidup mereka. Bagi manusia karena sebagian besar tubuh manusia terbentuk dari air. Persyaratan air untuk setiap kebutuhan tentu berbeda. Secara umum, semakin tinggi standar hidup, jumlah permintaan air juga akan meningkat. Pentingnya penggunaan air terutama untuk minum dan memasak..(Tombeng et al., 2013)

Permintaan akan kebutuhan air minum yang sehat dan higinis di masyarakat cenderung meningkat dengan populasi penduduk yang semakin berkembang dan ini tidak seimbang dengan jumlah air bersih yang tersedia. Yang menjadi penyebabnya antara lain adalah terjadinya polusi air tanah dan ini menyebabkan penggunaan air tersebut tidak lagi sehat dan aman lagi untuk digunakan sebagai air minum. (Marpaung \& Marsono, 2013)

Banyak cara dalam memenuhi kebutuhan air minum di masyarakat. Di perkotaan masyarakat banyak menggunakan Air Minum Dalam Kemasan (AMDK) yang dinilai cukup praktis, mudah didapat serta higienis. Seiring dengan kebutuhan AMDK yang semakin meningkat maka ada pula pilihan alternatif lain yaitu Air Minum Isi Ulang (AMIU) yang produsennya adalah Depot Air Minum Isi Ulang (DAMIU) yang merupakan suatu usaha pengelolaan air minum untuk kebutuhan masyarakat 
Volume 6, Nomor1, Juni-Desember 2021

dan tidak dalam kemasan. Harga yang ditawarkan AMIU tentunya lebih murah dari AMDK dan saat ini AMIU adalah alternatif solusi pemenuhan kebutuhan air minum masyarakat di Indonesia karena kepraktisan dan harganya yang relatif murah.

Tersedianya air yang bersih untuk keperluan rumah tangga yaitu air minum, harus sesuai dengan syarat - syarat yang terdapat dalam peraturan internasional maupun peraturan nasional dan daerah. Kualitas air minum di Indonesia harus sesuai dengan persyaratan yang terdapat dalam Peraturan Menteri Kesehatan Kesehatan Republik Indonesia No. 492 / Menkes / Per / IV / 2010 Di mana setiap komponen yang diizinkan dalam kandungannya harus memenuhi syarat standar air minum yang sehat yang mencakup persyaratan fisik, kimia dan biologis. (Wandrivel et al., 2012).

Tujuan dari Penelitian ini adalah untuk mengetahui kualitas Air Minum Isi Ulang yang diproduksi oleh beberapa Depot Air Minum di daerah Kenten dan sekitarnya ditinjau dari Parameter Fisika, Kimia dan Biologi dan juga apakah kualitas Air Minum Isi Ulang yang diteliti sudah memenuhi kriteria kualitas Air Minum sesuai standar yang ditetapkan oleh Kementrian Kesehatan Republik Indonesia.

Menurut Permenkes No. 492/Th.2010, 2010) Air minum adalah air yang diolah atau tidak diolah dan memenuhi syarat kesehatan dan bisa langsung diminum. Air yang aman diminum dan sehat adalah air yang memenuhi persyaratn fisik, kimia dan biologi serta radioaktif. Sebagaimana halnya makanan dan udara, tubuh manusia juga memerlukan air. Tidak adanya air menyebabkan manusia tidak bertahan lama. Kegunaan air adalah untuk menunjang kehidupan manusia antara lain tersedia dalam kondisi yang bersih dan sehat sehingga layak minum tanpa menganggu kesehatan .(Direktorat Penyehatan Lingkungan, 2010).

Fungsi air minum untuk tubuh manusia adalah mempertahankan metabolisme agar seimbang dan fisiologi tubuh. Disamping itu, air berguna sebagai pelarut dalam proses pengolahan makanan sehingga dapat dicerna oleh tubuh. Jika ada kekurangan air, sel-sel tubuh akan menyusut dan tidak dapat bekerja dengan baik dan air juga merupakan ekskresi cairan (keringat, air mata, urin, uap pernapasan dan cairan tubuh lainnya. tubuh manusia sebagian besar terdiri dari air. Umumnya, berat badan manusia ngan lemak dan tulang, $77 \%$ berada dalam daging, paru-paru dan ginjal ada $80 \%$, dan di plasma 90 - 95,5\%. Artinya semua makhluk hidup tubuhnya terdiri dari air.

Kebutuhan masyarakat akan air minum dapat teratasi dengan adanya Air Minum Isi Ulang yang bisa dibeli di Depot - Depot. Dengan harga yang relatif murah yang tentu saja harganya tidak semahal air kemasan dengan merk maka banyak masyarakat yang kemudian beralih pada Air minum isi ulang dan ini tentu saja menyebabkan pesatnya pertumbuhan Depot air minum di berbagai daerah

Menurut Chandra (2006) dalam (Kuswanto, Heri, 2013) Air yng akan dikonsumsi manusia harus diperoleh dari sumber yang bersih dan aman. Persyaratannya adalah antara lain, bebas dari kontaminasi bakteri dan sumber penyakit, bebas dari bahan kimia berbahaya dan beracun, tanpa rasa dan tanpa bau, dapat digunakan untuk memenuhi kebutuhan rumah tangga dan sesuai standar minimum yang ditetapkan.

\section{METODELOGI PENELITIAN}

Penelitian dilakukan dengan metode eksperimen di Laboratorium . Dengan cara menganalisa beberapa sampel yang diambil dari beberapa depot air minum isi ulang di daerah Kenten Laut Kabupaten Banyuasin dan beberapa merk sampel air minum kemasan yang beredar disekitar keneten laut.

Prosedur Penelitian

1. Pengambilan sampel

Sampel air minum isi ulang berasal dari depot air minum isi ulang dan air minum kemasan yang berada di daerah Kenten Laut dan sekitarnya. 
2. Prosedur pengecekan Warna ,Bau dan Rasa

Pada bagian ini dilakukan Uji Organoleptik dari beberapa responden untuk menilai perbandingan sampel yang ada.

3. Pengukuran temperatur dengan termometer.

4. Pengukuran $\mathrm{pH}$

- Kalibrasi pH dengan larutan standar pH 7. Kemudian ukur pH yang didapat

5. Prosedur pengujian Total Dissolved Solid (TDS)

- Kalibrasi TDS meter dengan Larutan $\mathrm{NaCl}$ 1000ppm

- Setelah TDS meter selesai di kalibrasi, ambil sampel dan masukkan TDS meter kedalam sampel, tunggu sampai angka pada TDS meter tidak berubah, dan lihat hasil TDS meter

6. Pengujian Bakteri

Prosedur pemeriksaan dan penentuan hasil

- Sediakan 1 tabung media.

- Memasukkan $20 \mathrm{cc}$ sampel air atau hingga tanda batas (melalui mulut tabung pada nyala api, untuk tetap steril)

- Letakkan di rak tabung di suhu ruang selama $1-3$ hari

- Jika tahap-tahap di atas telah dilakukan, pembacaan hasil untuk memastikan adanya bakteri coliform dalam air bersih dalam pemerikasaan sampel dapat dilakukan dengan dua cara, kualitatif dan semi kualitatif.

- Hasil secara kualitatif, negatif jika tidak ada perubahan warna, hasil positif (+), jika ada perubahan warna pada media menjadi hitam / kehitaman

\section{HASIL DAN PEMBAHASAN}

Hasil pengujian parameter Fisika, Kimia, Biologi, dengan mengacu standar Permenkes RI No.492/Menkes/Per/IV/2010 sebagai berikut :

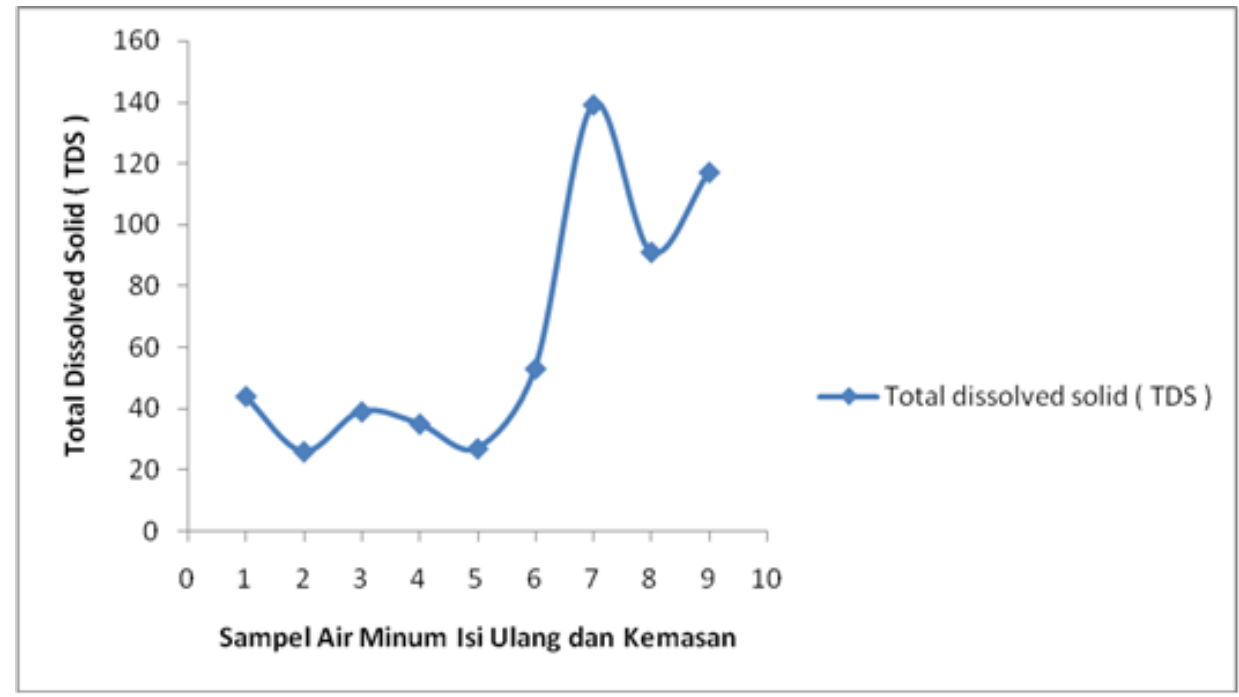

Gambar 1. Grafik analisa sampel air minum isi ulang dan kemasan terhadap nilai (TDS).

Dari gambar 1 dapat dilihat, hasil analisa TDS yaitu di dapat yang paling rendah terdapat pada sampel no 7 yaitu $27 \mathrm{ppm}$ dan TDS tertinggi didapat pada sampel no 8 yaitu $139 \mathrm{ppm}$. Nilai TDS ini masih dibawah kadar maksimum yang di tetapkan oleh Permenkes RI No.492/Menkes/Per/IV/2010 yaitu 500 ppm yang artinya dari sembilan sampel yang dianalisa semuanya masih memenuhi standar 
yang ditetapkan Jika kadar TDS melewati batas maksimum maka akan menyebabkan rasa airnya menjadi tidak enak dan menimbulkan mual, jika zat padat terlarut berasal dari senyawa Natrium sulfat dan Magnesium Sulfat maka mengakibatkan terjadinya cardiac diseases serta toxemia pada wanita hamil (Pulungan \& Away, 2019).

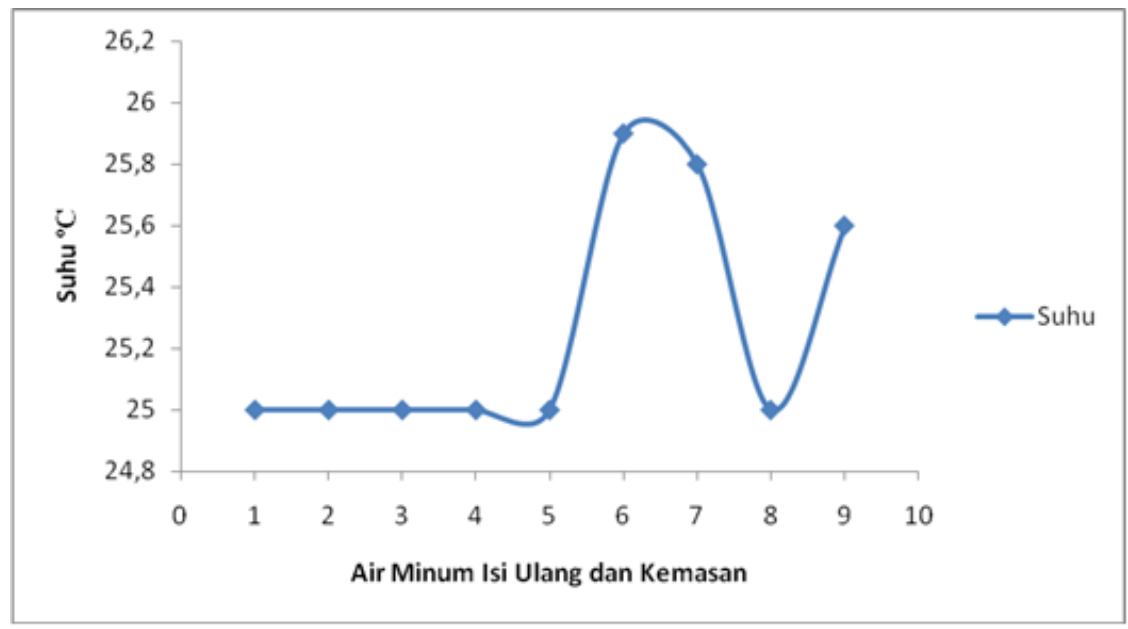

Gambar 2. Grafik analisa sampel air minum isi ulang dan kemasan terhadap Temperatur

Dari hasil analisa, temperatur yang paling rendah terdapat pada sampel no 1, 2, 3, 4, 5 yaitu $25^{\circ} \mathrm{C}$ dan Temperatur tertinggi didapat pada sampel no 6 yaitu $25,9^{\circ} \mathrm{C}$. Berdasarkan Permenkes RI No.492/Menkes/Per/IV/2010, temperatur maksimum yang diizinkan dalam air minum adalah $\pm 25^{\circ} \mathrm{C}$ artinya dari sembilan sampel yg dianalisa semuanya masih memenuhi persyaratan yang ditetapkan.

Untuk rasa dari beberapa sampel tersebut memiliki rasa yang berbeda-beda, sampel 1 rasanya kecut dan asam, sampel 2 rasanya asam, sampel rasanya pahit, lengket, dan kelat, sampel 4 tidak memiliki rasa, sampel 5 memiliki rasa sedikit pahit, sampel 6 memiliki rasa pahit, lengket, kelat, dan sepat, sampel 7 rasanya sedikit seperti rasa kelapa, sampel 8 memiliki rasa kelapa dan cenderung manis, sampel 9 memiliki rasa seperti rasa kelapa yang kuat dan manis.

Hasil analisa $\mathrm{pH}$ yang didapatkan dari beberapa depo di Kenten Laut dan beberapa air minum kemasan terlihat pada gambar 3. berikut ini :

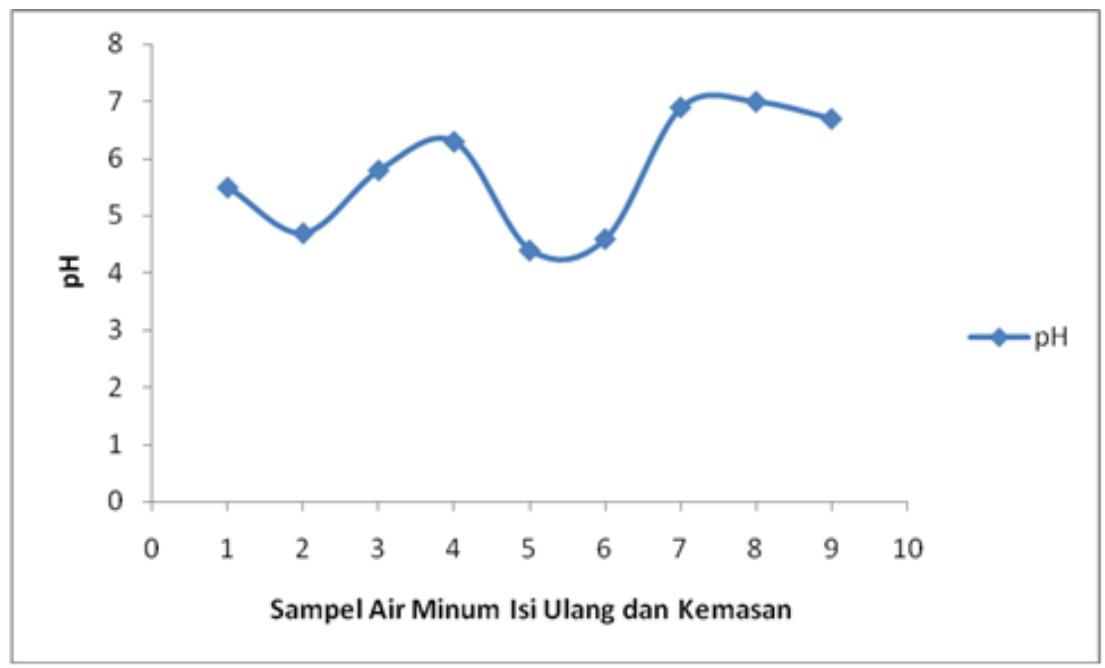

Gambar 3. Grafik analisa sampel air minum isi ulang dan kemasan terhadap pH. 


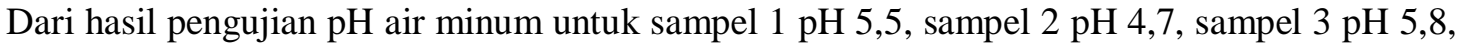
sampel $4 \mathrm{pH}$ 6,3, sampel $5 \mathrm{pH}$ 4,4, sampel $6 \mathrm{pH}$ 4,6, nilai $\mathrm{pH}$ ini dibawah kadar yang diperbolehkan, dimana Permenkes RI No.492/Menkes/Per/IV/2010, pH yang diperbolehkan untuk air minum sekitar 6,5-8,5. pH air yang normal berada di antara 6-8, pada industri makanan, peningkatan keasaman air buangan umumnya disebabkan oleh kandungan asam organik (Pulungan \& Away, 2019).

Pemeriksaan air secara biologis sangat penting untuk mengetahui adanya kandungan mikroorganisme yang terdapat dalam air. Terdapatnya bakteri esherichia-coli yang merupakan bakteri yang sifatnya patogen dalam air minum tentu saja akan menimbulkan resiko terhadap kesehatan dan akan menyebabkan kerusakaan dan menurunnya kualitas air.(Afrianti Rahayu \& Muhammad Hidayat Gumilar, 2017)

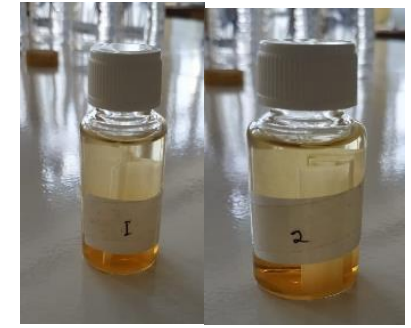

Sampel sebelum di analisa

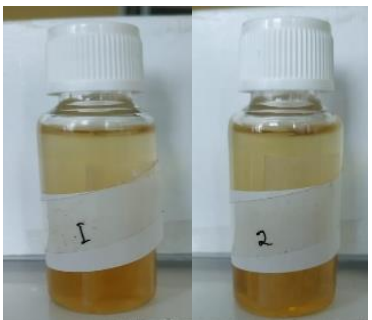

Sampel setelah 2 hari

Gambar 4. Hasil analisa bakteri e-coli dengan metode $\mathrm{H}_{2} \mathrm{~S}$

Dari hasil analisa yang dilakukan terhadap sembilan sampel yang dilakukan dengan metode $\mathrm{H}_{2} \mathrm{~S}$, indikasi adanya bakteri e-coli tidak ditemukan, ini dapat dilihat dari gambar 4.dengan metode $\mathrm{H}_{2} \mathrm{~S}$ tidak terjadi perubahan warna. Jika terdapat bakteri dalam sampel, maka gas hidrogen sulfid yang dihasilkan oleh bakteri tersebut akan membuat kertas strip berubah menjadi hitam, dari hasil analisa $\mathrm{H}_{2} \mathrm{~S}$ yang dilakukan terhadap sembilan sampel kertas stripnya tidak berubah warna. Artinya sampel air minum isi ulang dan kemasan tidak terkontaminasi bakteri E.coli. Jadi air minum isi ulang dan kemasan tersebut sesuai dengan standar Permenkes RI No.492/Menkes/Per/IV/2010.

\section{KESIMPULAN}

Dari hasil analisa parameter fisika, pada rasa sampel 1 sampai 9 memiliki rasa, pahit, asam, kelat, lengket, sepat, dan beraroma kelapa, kecuali pada sampel 4 tidak berasa. Untuk parameter Kimia, pada sampel 1 sampai 6 memiliki pH cenderung asam 4,4-5,8. Sedangkan kontaminasi bakteri E.coli tidak di temukan dari 9 sampel. Dari hasil analisa menunjukan bahwa masih ada beberapa parameter yang masih belum memenuhi persyaratan Permenkes RI No. 492/Menkes/Per/IV/2010.

\section{DAFTAR PUSTAKA}

Afrianti Rahayu, S., \& Muhammad Hidayat Gumilar, M. (2017). Uji Cemaran Air Minum Masyarakat Sekitar Margahayu Raya Bandung Dengan Identifikasi Bakteri Escherichia coli. Indonesian Journal of Pharmaceutical Science and Technology, 4(2), 50. https://doi.org/10.15416/ijpst.v4i2.13112

Direktorat Penyehatan Lingkungan. (2010). Pedoman Pelaksanaan Penyelenggaraan Hygiene Sanitasi Depot Air Minum. 
Kuswanto, Heri, S. (2013). Pemeriksaan Mikrobiologis Air Minum Isi Ulang di Wilyah Kecamatan Kuala kabupaten Nagan Raya. Universitas Teuku Umar, Aceh Barat.

Marpaung, M. D. O., \& Marsono, B. D. (2013). Uji Kualitas Air Minum Isi Ulang di Kecamatan Sukolilo Surabaya Ditinjau dari Perilaku dan Pemeliharaan Alat. JURNAL TEKNIK POMITS Vol. 2, No. 2, (2013) ISSN: 2337-3539 (2301-9271 Print), 2(2), 2-6.

Permenkes No. 492/Th.2010. (2010). Persyaratan Kualitas Air Minum. In Peraturan Mentri Kesehatan Republik Indonesia (Issue 492).

Pulungan, S. A., \& Away, Y. (2019). Analisa Kualitas Air Minum Isi Ulang Ditanjung Pati. Lumbung, 18(1), 10-19. https://doi.org/10.32530/lumbung.v18i1.178

Tombeng, R. B., Polii, B., \& Sinolungan, S. (2013). Analisis Kualitatif Kandungan Escherichia coli dan Coliform Pada 3 Depot Air Minum Isi Ulang di Kota Manado. Jurnal Kesehatan Masyarakat Universitas Sam Ratulangi., 492, 5-9. https://ejournal.unsrat.ac.id/index.php/JKKT/article/view/11273

Wandrivel, R., Suharti, N., \& Lestari, Y. (2012). Kualitas Air Minum Yang Diproduksi Depot Air Minum Isi Ulang Di Kecamatan Bungus Padang Berdasarkan Persyaratan Mikrobiologi. Jurnal Kesehatan Andalas, 1(3), 129-133. https://doi.org/10.25077/jka.v1i3.84 